\title{
Relationship between Cutler Mormon-Tea [Ephedra cutleri] and Coppice Dunes in Determining Range Trend in Northeastern Arizona
}

\author{
HARMON S. HODGKINSON
}

\begin{abstract}
Range trend is one of the basic components of rangeland inventories. Understanding the interactions between soil, climatic factors, and vegetation aids the range manager in determining and predicting trend. Coppice dunes, dune interspace, and vegetation were evaluated in northeastern Arizona. Soil with a surface layer of loamy fine sand is susceptible to wind erosion. If Cutler Mormontea is part of the plant community, coppice dunes may form. Range trend can be determined and predicted by observing the status of the coppice dunes, the dune interspace, and their vegetation.
\end{abstract}

Range managers make inventories that are used to develop quality range management plans. Range condition and trend are two basic components of the inventory. Range condition is the present state of vegetation in relation to the natural potential plant community for the site. Range trend is a determination of the direction of change in range condition or what is currently happening to the plant community.

Interactions between soil and vegetation are important in understanding range trend. If the range manager can understand the cause of soil movement and the reaction of vegetation, current range trend can be better determined and gross trend changes can be predicted. Many rangelands in low precipitation areas are unable to support a complete plant cover. Bare ground is natural and provides a source for some local soil movement. However, any decreases in plant cover will accelerate soil surface movement.

The purpose of this study was to evaluate the soil and vegetation on coppice dunes and dune interspaces in order to understand how the dunes and vegetation might be related to current range trend and gross trend changes.

\section{Study Area}

The study was conducted during the summer of 1981 on the Hopi Indian Reservation in central Navajo County, Ariz. The study site is about $105 \mathrm{~km}$ (65 miles) northeast of Flagstaff and is part of the Colorado and Green River Plateau major land resource area. The area is typified by long, broad rolling mesas and plains dissected by major drainages. The closest villages are Oraibi, 35 kilometers (22 miles) north, and Seba Dalkai, 18 kilometers (11 miles) southeast on the Navajo Indian Reservation. Annual precipitation at Oraibi is 195 millimeters (7.69 inches) and at Seba Dalkai 184 millimeters ( 7.24 inches). About $55 \%$ of the annual precipitation is received in summer thundershowers that are typical of storms in the Southwest. The other $45 \%$ falls as snow in the winter months. June is the driest month. Mean annual temperature at

Author is range conservationist, Soil Conservation Service, 2717 North Fourth Street Suite 140, Flagstaff, Ariz. 86001

The author thanks Robert J. Ahrens and Deborah J. McKeown, Soil Scientists, SCS, Flagstaff, for assistance with the soil evaluation.

Manuscript received April 15, 1982.
Oraibi is $10.9^{\circ}$ C. $\left(51.9^{\circ}\right.$ F.) and at Seba Dalkai $11.7^{\circ}$ C. $\left(53.4^{\circ}\right.$ F.). The elevation at the study site ranges from 1615 meters ( 5300 feet) to $1706 \mathrm{~m}$ ( 5600 feet). Drying winds in spring are generally from a southwestern direction.

\section{Methods}

\section{Vegetation}

The present plant communities were evaluated on the coppice dunes and dune interspaces. Care was taken to sample each plant community separately. Plant composition and yield were determined by the "double-sampling" method used by the Soil Conservation Service (USDA 1976). In the procedure, $10-1-\mathrm{m}^{2}(9.6 \mathrm{sq} . \mathrm{ft}$.) plots were randomly selected on the area to be sampled. All plant species were estimated by weight for each plot. Individual species on the 2 most representative plots were harvested and weighed. Plot correction factors were applied to the estimations.

Soils

Pits were dug $165 \mathrm{~cm}$ (65 inches) deep with a backhoe in the coppice dune and the dune interspace for comparison. Soil characteristics were determined by methodology given in the Soil Survey Manual (Soil Survey Staff 1951), and Soil Taxonomy (Soil Survey Staff 1975). The soil in the coppice dune and in the dune interspace areas both are of the Sheppard series, a member of the mixed, mexic Typic Torripsamments.

\section{Results and Discussion}

A landscape that has coppice dunes or the potential for coppice dunes must have soil that is susceptible to wind movement, wind, and vegetation that will withstand deposition.

Coppice dunes are soil deposits formed by wind in conflict with bunch or clump vegetation (Melton 1940). Dunes develop within or to the leeward side of plants that can withstand rapid soil deposition. In Nevada, Wood et al. (1978) found that coppice dunes formed from silt and very fine sands. Near Las Cruces, New Mexico, Gile and Grossman (1979) found that soils that have a sand, loamy sand, or light sandy loam surface layer form coppice dunes. The area between the coppice dunes is defined as dune interspace (Melton 1940).

The Sheppard soil on this study site has a texture of loamy fine sand. It formed from the Navajo Sandstone formation that is extensive in this area.

The soils, whether in the coppice dunes or the dune interspace, were described identically with the exception of surface structure. On the coppice dune, the structure to a depth of $5 \mathrm{~cm}$ ( 2 inches) is weak thin platy over weak fine subangular blocky. On the dune interspace, the structure to a depth of $13 \mathrm{~cm}$ (5 inches) is weak 
medium and thick platy over weak fine and medium subangular blocky.

Another difference between the Sheppard soil in the coppice dune and that in the dune interspace is the depth of the recent depositional layer. In the coppice dune the depth ranged from 30 to $92 \mathrm{~cm}$ ( 12 to 36 inches); in the dune interspace, it ranged from 7.6 to $13 \mathrm{~cm}$ ( 3 to 5 inches).

The height of the coppice dune is related to the amount of erosion and deposition that has occurred. Anderson (1974) states that the difference between a mound and an adjacent scoured area represents both erosion and deposition.

Past soil movement is evident in the topography of the Sheppard soil (Fig. 1). The coppice dunes on the study site have an average height of $0.9 \mathrm{~m}$ ( $3 \mathrm{feet})$, with a minimum of $0.6 \mathrm{~m}$ ( 2 feet) and a maximum of $1.8 \mathrm{~m}$ (6 feet). The average diameter is $6.1 \mathrm{~m}(20 \mathrm{feet})$ with a minimum of $3.0 \mathrm{~m}$ ( $10 \mathrm{feet})$ and a maximum of $13.7 \mathrm{~m} \mathrm{(45}$ feet). The dune interspace averages $12.1 \mathrm{~m}$ (40 feet) with a minimum of $30 \mathrm{~m}$ (10 feet) and a maximum of $18.3 \mathrm{~m}$ (60 feet).

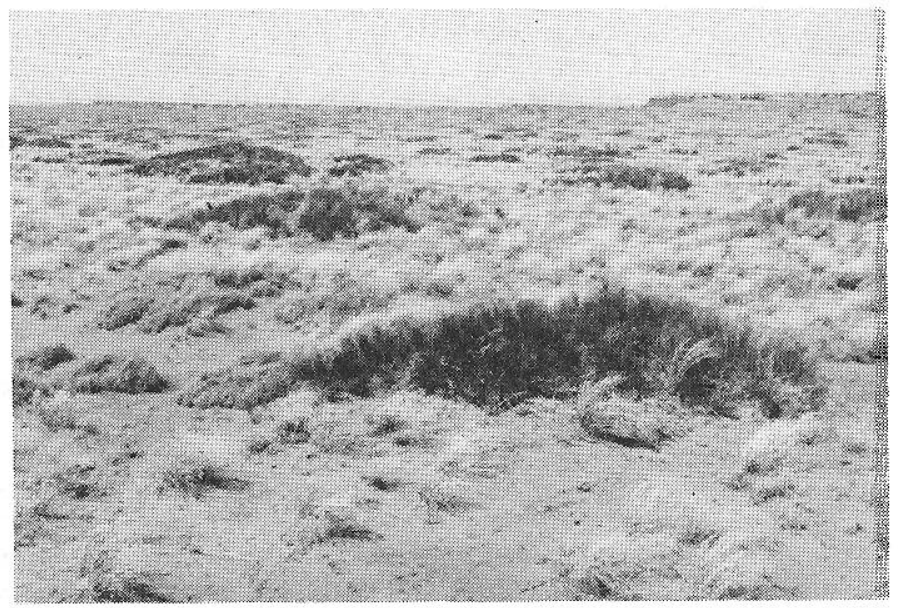

Fig. 1. Coppice dunes are dominated by Cutler Mormon-tea indicating past wind erosion on Sheppard soil. Indian ricegrass is the major species of the dune interspace.

Wind is the second requirement for the formation of coppice dunes. The closest weather station recording representative wind speeds is at Winslow, about 80 kilometers (50 miles) south of the study site (Sellers and Hill 1974). The study area lies in the windiest part of the state where sandstorms are quite common in late winter and spring. Also, strong winds usually precede summer thunderstorms capable of causing wind erosion. The strongest maximum winds range from $64.3 \mathrm{~km} /$ hour $(40.0 \mathrm{mph})$ to $73.2 \mathrm{~km} /$ hour $(45.5$ $\mathrm{mph}$ ) occurring in late winter and spring afternoons. The winds that precede summer thunderstorms reach a maximum of 55.8 $\mathrm{km} /$ hour (34.7 $\mathrm{mph}$ ) in the afternoon.

Plants that survive on coppice dunes are those adapted to loose aeolian deposits and typically have rhizomes. In southern New Mexico, Gile and Grossman (1979) found mesquite (Prosopis juliflora) to be the dominant plant on coppice dunes, with an occasional fourwing saltbush (Atriplex canescens). Cutler Mormon-tea (Ephedra cutleri), an evergreen shrub that has strong rhizomes, was the major plant on the coppice dunes in the study site (Table 1). Like mesquite, Cutler Mormon-tea can withstand rapid soil deposition. Indian ricegrass (Oryzopsis hymenoides), broom snakeweed (Guiterrezia sarothrae), and fourwing saltbush were also present in minor amounts.

Cutler Mormon-tea is a minor part of the potential plant community for the undisturbed Sheppard soil (Fig. 2). The shrub is inconspicuous with Indian ricegrass the major grass species. After erosion occurs and coppice dunes are formed, the Mormon-tea becomes extremely visible (Figure 3). On the dune interspace, Indian ricegrass, galleta (Hilaria jamesii), and broom snakeweed are the major plants (Table 1).
Table 1. Species, composition, and total annual yield in Coppice Dune and Dune Interspace Soils.

\begin{tabular}{|c|c|c|c|}
\hline \multicolumn{2}{|c|}{ Species } & \multicolumn{2}{|c|}{$\begin{array}{l}\text { Composition (\%) } \\
\text { (air-dry weight) }\end{array}$} \\
\hline Common Name & Scientific Name & Dune & Interspace \\
\hline \multicolumn{4}{|c|}{ Grasses } \\
\hline Fendler threeawn & Aristida fendleriana & & 1 \\
\hline Galleta & Hilaria jamesii & & 5 \\
\hline Sandhill muhly & Muhlenbergia pungens & & $I$ \\
\hline Indian ricegrass & Oryzopsis hymenoides & 25 & 81 \\
\hline Mesa dropseed & Sporobolus flexuosus & & 1 \\
\hline Needleandthread & Stipa comata & & 1 \\
\hline \multicolumn{4}{|c|}{ Forbs } \\
\hline Heath aster & Leucelene ericoides & & 1 \\
\hline Russian thistle & $\begin{array}{l}\text { Salsola kali var. } \\
\text { tenuifolia }\end{array}$ & 1 & 1 \\
\hline $\begin{array}{l}\text { Smallflower } \\
\text { globemallow }\end{array}$ & Sphaeralcea parvifolia & 1 & \\
\hline Golden crownbeard & $\begin{array}{r}\text { Verbesina encelioides } \\
\text { var. exauriculata }\end{array}$ & 1 & \\
\hline \multicolumn{4}{|c|}{ Shrubs } \\
\hline Fourwing saltbush & Atriplex canescens & 1 & 1 \\
\hline Cutler Mormon-tea & Ephedra cutleri & 68 & \\
\hline Winterfat & Durotia lanata & & 1 \\
\hline Broom snakeweed & Gutierrezia sarothrae & 3 & 5 \\
\hline Fineleaf yucca & Yucca angustissima & & 1 \\
\hline \multicolumn{2}{|c|}{ Total percentage 100} & 100 & 100 \\
\hline otal annual yield & $(\mathrm{lb} / \mathrm{ac})$ & $(260)$ & $409(365)$ \\
\hline
\end{tabular}

To determine trend in range condition, several factors must be evaluated to know whether the plant community and soil changes are improving (upward trend) or declining (downward trend) from the potential for the site. After determining trend, the proper use, management, and treatment of the resource can be planned and applied.

The major factors used to indicate trend are the abundance of seedlings and young plants, plant vigor, species composition changes, plant residues and the condition of the soil surface (presence or absence of erosion). All or several factors must be considered in relation to each other for a sound determination of trend. The importance of these factors vary accordingly to different climate, soils, vegetation and the past and/or present grazing management.

There is much conjecture as to the cause of erosion in the Southwest. Most researchers (Thornthwaite et al. 1942, Antevs 1952) believe a combination of drought and overgrazing leaves the soil surface vulnerable to wind and water erosion.

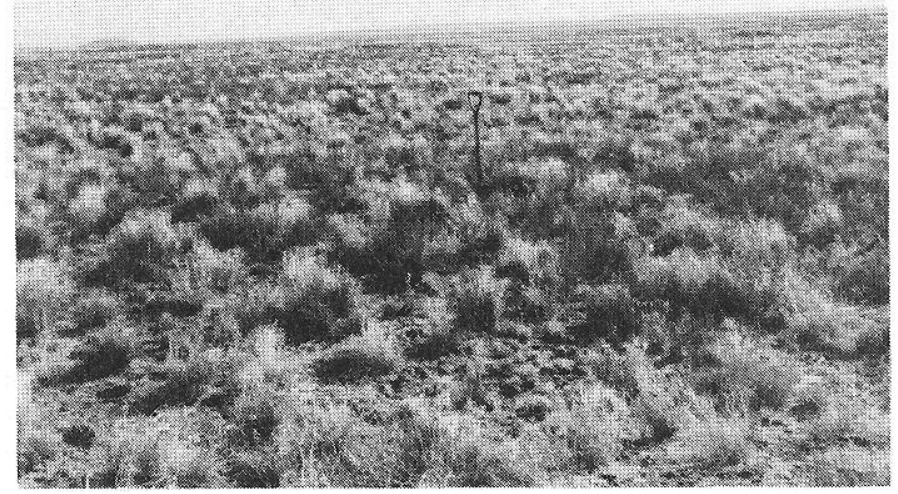

Fig. 2. The potential plant community on the undisturbed Sheppard soil is a mixture of Cutler Mormon-tea and Indian ricegrass. Tile spade height is $114 \mathrm{~cm}$ (45 inches). 


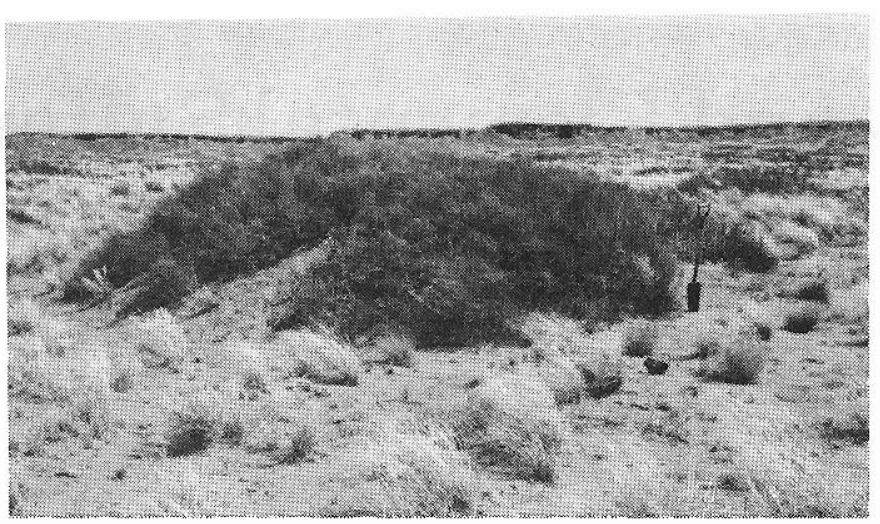

Fig. 3. Coppice dune $130 \mathrm{~cm}$ (5I inches) high covered with Cutler Mormon-tea. Tile spade height is $114 \mathrm{~cm}$ (45 inches).

A natural plant community develops in equilibrium with its given climate. Plants may increase or decrease in size and frequency as the climate fluctuates. Where precipitation is low, vegetation may just barely protect the soil surface from excessive erosion. The margin to protect the soil is slight. Only light grazing and in some cases, no grazing can be permitted and still provide soil protection by the vegetation in drought years. Bryan (1950) concluded that "overgrazing appears to have been merely a trigger pull which timed the explosive proccess that was imminent from climatic causes."

In this study, only the soil factor (coppice dunes) in relation to the plant community were evaluated in determining trend. However, it can be deducted that the presence of coppice dunes on the Sheppard soil indicates the range trend at sometime declined and still may be declining depending on other factors such as if the dune interspace is stabilized with undesirable or foreign plants to the potential plant community. Where there are no coppice dunes or none forming (the Cutler Mormon-tea being elevated by soil deposition), the range trend generally will be improving.

\section{Conclusion}

Range managers are better qualified in determining range trend and predicting gross trend changes through understanding the interactions of the soil, climatic factors, and vegetation.

In northeastern Arizona, soils susceptible to wind erosion must be managed carefully. Coppice dunes will form in areas of low precipitation, if the soils have a loamy fine sand surface layer, if there is considerable wind, if vegetation has been depleted, and if Cutler Mormon-tea is part of the plant community. Based on this criteria, where coppice dunes are forming, the range trend is down. If the coppice dunes have already formed and the dune interspace is stabilized with desirable plants of the potential plant community, the range trend is generally up.

\section{Literature Cited}

Anderson, E. William. 1974. Indicators of soil movement on range watersheds. J. Range Manage. 223:244-247.

Antevs, Ernst. 1952. Arroyo cutting and filling. J. of Geology. 60:375-385. Bryan, Kirk. 1950. Geologic interpretation of the deposits. In: Haury, E.W., the stratigraphy and archeology of Ventana Cave, Arizona. Univ. New Mexico Press. Albuquerque. p. 75-126.

Gile, Leland H., and Robert B. Grossman. 1979. The desert project soil monograph. USDA-SCS.

Melton, Frank A. 1940. A tentative classification of sand dunes: its application to dune history in the southern High Plains. J. Geology 48:113-174.

Sellers, William D., and Richard H. Hill. 1974. Arizona climate, 1931-1972. The Univ. Arizona Press; Tucson.

Soil Survey Staff. 1951. Soil survey manual. USDA Agr. Handbook No. 18.

Soil Survey Staff. 1975. Soil taxonomy; a basic system of soil classification for making and interpreting soil surveys. USDA Agr. Handbook No. 436.

Thornthwaite, C.W., C.F.S. Sharpe, and E.F. Dosch. 1942. Climate and accelerated erosion in the arid and semiarid Southwest, with special reference to the Polacca Wash drainage basin, Arizona. USDA Tech. Bull. 808 .

U.S. Department of Agriculture. 1976. National range handbook. Soil Conserv. Ser.

Wood, M.K., W.H. Blackburn, R.E. Eckert, Jr., and F.F. Peterson. 1978. Interrelations of the physical properties of the coppice dune and vesicular dune interspace soils with grass seedling emergence. J. Range Manage. 31:189-192. 